\title{
Nursing interventions in pain *
}

\author{
Intervenções de enfermagem na dor
}

\author{
Priscila de Oliveira da Silva ${ }^{1}$, Vera Catarina Portella²
}

${ }^{*}$ Received from Federal University of Rio Grande do Sul, Porto Alegre, RS, Brazil.

\section{ABSTRACT}

BACKGROUND AND OBJECTIVES: Nursing interventions are any care based on nurses' judgment and clinical knowledge, based on a scientifically supported action, carried out and planned for patients' benefit. These are very important to control pain since pain, when inadequately treated, affects the quality of life of patients and caregivers in physical, psychological, social and spiritual dimensions. So, this study aimed at identifying nursing interventions to handle pain and whether they relate to those proposed by the Nursing Interventions Classification.

CONTENTS: This is an integrative literature review, carried out in LILACS, Scielo and Medline databases. Nine articles published between 2001 and 2011 were selected. These articles describe nursing interventions to handle pain in different contexts.

CONCLUSION: Most nursing interventions mentioned by the articles are related to those described by the Nursing Interventions Classification. The scarcity of clinical studies related to nursing interventions to handle pain was also observed.

Keywords: Nursing, Pain, Pain handling.

\section{RESUMO}

JUSTIFICATIVA E OBJETIVOS: As intervenções de enfermagem referem-se a qualquer cuidado baseado no julgamento e conhecimento clínico do enfermeiro tendo por base uma ação fundamentada cientificamente, realizada e prevista em benefício do paciente. Estas assumem grande importância no

\footnotetext{
1. Clinicas Hospital of Porto Alegre, Porto Alegre, RS, Brazil.

2. Federal University of Rio Grande do Sul, School of Nursing, Porto Alegre, RS, Brazil.

Submitted in July 13, 2013.

Accepted for publication in April 08, 2014.

Conflict of interests: none.

Correspondence to:

Priscila de Oliveira da Silva

Rua Felipe de Noronha, 371/101

92020-300 Canoas, RS, Brasil.

E-mail: enfprisilva@gmail.com

(C) Sociedade Brasileira para o Estudo da Dor
}

controle da dor, uma vez que a dor, quando náo tratada adequadamente, afeta a qualidade de vida dos pacientes e de seus cuidadores nas dimensóes física, psicológica, social e espiritual. Sendo assim, o objetivo deste estudo foi conhecer as intervençóes utilizadas pelos enfermeiros para o manuseio da dor e se estas se relacionam com as propostas pela Nursing Interventions Classification.

CONTEÚDO: Trata-se de uma revisão integrativa da literatura, realizada nas bases de dados LILACS, Scielo e Medline. Foram selecionados nove artigos publicados entre 2001 e 2011. Esses artigos descrevem intervençóes de enfermagem prestadas para o manuseio da dor em diferentes contextos.

CONCLUSÁO: A maioria das intervençóes de enfermagem citadas nos artigos possui relação com as descritas pela Nursing Interventions Classification. Também foi observada a carência de estudos clínicos relacionados às intervençóes de enfermagem para manuseio da dor.

Descritores: Dor, Enfermagem, Manuseio da dor.

\section{INTRODUCTION}

Nursing Assistance Systematization (NAS) has helped nursing teams to organize and direct their actions to the specific needs of each patient, in a context where the individual is seen as a whole. Started in the1950s, NAS is becoming increasingly necessary in health institutions where nursing actions are developed, aiming at offering humanized care to patients ${ }^{1}$.

Supported by resolutions of the Federal Council of Nursing ${ }^{2,3}$, the Nursing Process (NP), by means of NAS, allows assistance to be planned to meet specific patients' needs, through a holistic approach which helps assuring that interventions are individually planned ${ }^{1}$.

Nursing Diagnosis (ND), essential NP stage, is the basis for the choice of adequate interventions for each patient. Currently, classification systems standardize the language used by nurses to define health problems faced by patients, through diagnostic terminologies, of which the North American Nursing Diagnosis Association International (NANDA) ${ }^{4}$ is the most popular.

An accurate ND leads nurses to prepare an assistance plan with adequate nursing interventions in a case-by-case basis. These interventions are any care based on nurses' judgment and clinical knowledge, based on a scientifically supported action, carried out and planned for patients' benefit ${ }^{5}$.

These are very important to control pain since pain, when inadequately treated, affects the quality of life (QL) of patients 
and caregivers in physical, psychological, social and spiritual dimensions.

Nursing teams have a taxonomy which includes actions recommended for care, such as Nursing Interventions Classification (NIC), which aims at improving clinical documentation, communication of the intervention, data integration in automated systems, data utilization by nurses from different clinics and institutions, and is a data source for studies, productivity indicators, evaluation of competence, payment for services and curricular structuring ${ }^{6}$.

However, even with classification systems and pain measurement tools, pain is still underidentified and undertreated ${ }^{7}$, fact which may impair patients' recovery and negatively impact their QL.

It is possible to infer that a difficulty to adequately handle pain is the inadequacy of pain evaluation models and gaps in health professionals' qualification about pain and analgesia, resulting in the incorrect use of analgesic therapies, which may be considered as possible causes of insufficient pain relief'.

To better understand nursing actions when handling pain in different care contexts, we decided to carry out this study with the purpose of understanding nursing actions to handle pain and check whether they are related to those proposed by NIC. With this, it is possible to enhance nursing actions, providing subsidies for critical thinking development of effective assistance plans to meet the needs of each patient, especially those feeling pain.

\section{CONTENTS}

This is an integrative literature review. The guiding question was: which are nursing interventions to handle pain that are being described in the literature?

As from this question, articles from LILACS, Scielo and Medline (via National Library of Medicine) were included. The query used Health Sciences Descriptors (DeCS) from the Medicine Regional Library BIREME: pain, nursing and interventions. The Boolean operator AND was used to combine DeCS.

Articles addressing nursing interventions to handle pain in adult patients, written in Portuguese, Spanish or English, in the period between 2001 and 2011, and fully available for free were included. We decided for a 10-year period because an increase in the number of publications, especially nursing publications, was observed during this period.

To put together the database, information extracted from articles were summarized and organized through a data collection tool containing title, authors, publication year, journal, language, objective, type of study and nursing interventions. After detailed analysis of the articles, nine studies were selected, of which six were published in the last five years, fact that shows the increasing interest for this subject in recent years, especially with regard to nursing interventions.

Most studies (six) were review articles, systematic reviews and literature reviews. Remaining articles were exploratory retrospective research, case-control study and case study (Table 1). These data show that nursing is still focused on review studies, carrying out few clinical studies, especially in this area. Nursing daily practice is rich in situations which would justify the development of clinical studies to improve painful patients' assistance.

It is important to stress the number of articles published in Brazilian journals, showing that Brazilian nursing is dedicated to producing studies involving pain-related nursing interventions. Interventions similar to those described by NIC with their respective frequencies were: analgesic and drug administration (4), cold/heat application (3), assistance to patient-controlled analgesia (PCA) (1), environment control: comfort (2), pain control (6), energy control (1), recreation (2), teaching: procedure/treatment (3), imagination stimulation (1), coping improvement (1), massage (2), music therapy (1), progressive muscular relaxation (1) relaxation therapy (1) and touch (1) (Table 2).

Some interventions described by articles were not part of NIC, such as decreasing anxiety (1), scent therapy (2) and sleep promotion (1).

Some articles ${ }^{5,12}$ have used the intervention pain control, as well as its activities, showing the importance of using a standardized language for nursing assistance to painful patients. Other articles ${ }^{8}$ have mentioned only some activities of this intervention, such as analgesic and drug administration, which may represent a difficulty in distinguishing between interventions and activities.

Table 1. Sample characterization

\begin{tabular}{|c|c|c|c|}
\hline Cod. & Authors & Methodology & Studied population \\
\hline $1 \mathrm{~A}$ & Paula et al. ${ }^{8}$ & Systematic review (BIREME) & Orthopedic patients \\
\hline $2 \mathrm{~A}$ & Restrepo-Medrano e Rojas ${ }^{9}$ & Thematic review & Fibromyalgia patients \\
\hline $3 A$ & Abreu et al. ${ }^{10}$ & Systematic review & Breast cancer patients \\
\hline $4 \mathrm{~A}$ & Popov \& Peniche ${ }^{11}$ & $\begin{array}{l}\text { Exploratory, retrospective, descriptive with quan- } \\
\text { titative approach }\end{array}$ & Patients in post-anesthetic recovery \\
\hline $5 \mathrm{~A}$ & Gomes et al. ${ }^{12}$ & Case study & Churg-Strauss syndrome patients \\
\hline $6 \mathrm{~A}$ & da Silva \& Marques ${ }^{13}$ & Literature review & Sickle cell anemia patients \\
\hline $7 \mathrm{~A}$ & Rigotti \& Ferreira ${ }^{5}$ & Review article & Patient with pain \\
\hline $8 \mathrm{~A}$ & Heye et al. ${ }^{14}$ & Case-control study & Patients in preoperative period \\
\hline $9 \mathrm{~A}$ & Niño ${ }^{15}$ & Review article & Burned patients \\
\hline
\end{tabular}


Table 2. Description of interventions

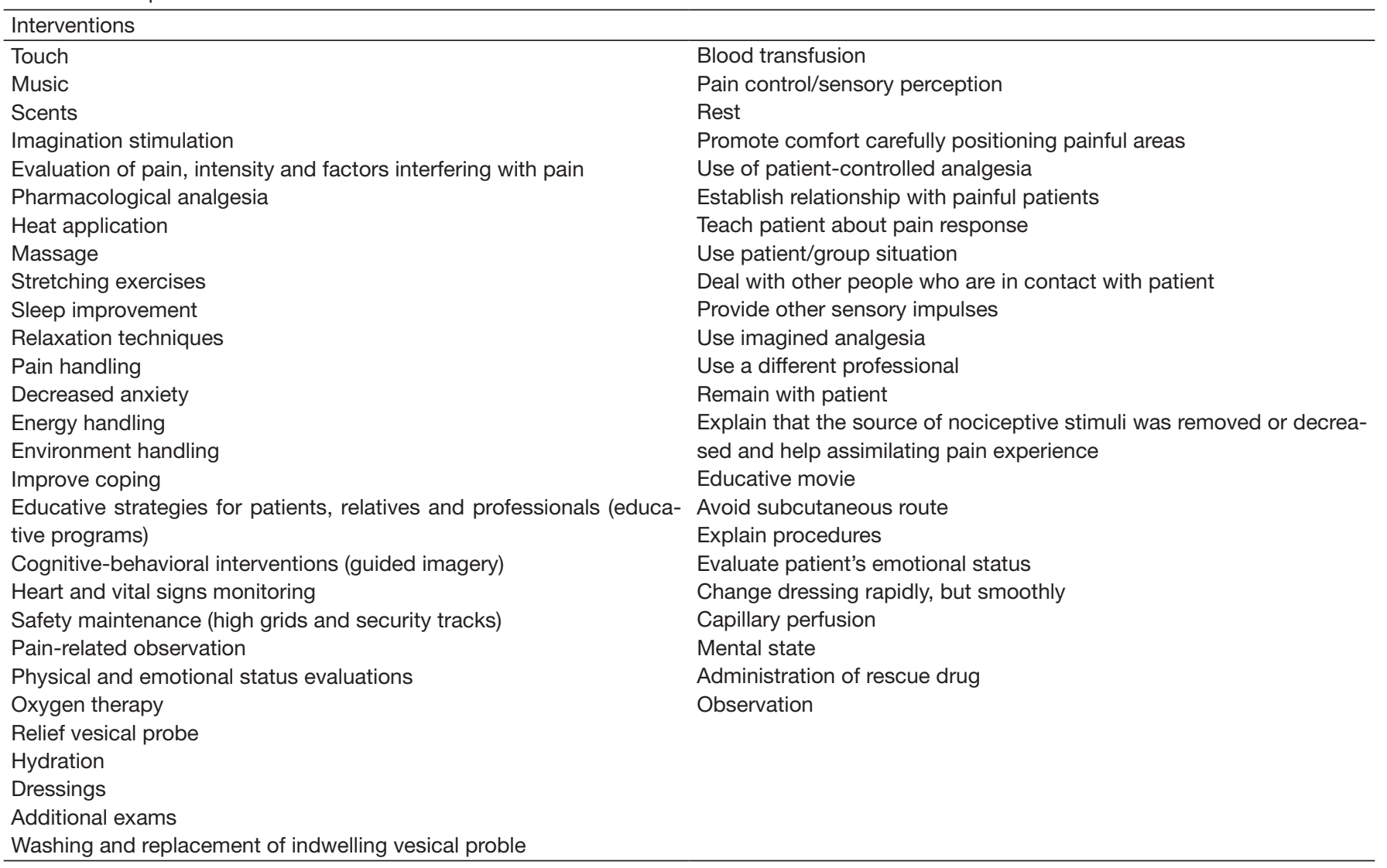

Nursing intervention is described by NIC as "any treatment, based on judgment and clinical knowledge, carried out by a nurse to improve patient/client results. Nursing interventions include both direct and indirect assistance, those focusing on individuals, relatives and communities, and those for treatments started by nurses, physicians or other caregiver" ${ }^{16}$.

Activities, on the other hand, are defined as "specific nurses' behaviors or actions to implement an intervention and which help patients/clients to advance toward expected results. Nursing activities are within a concrete action level. A series of activities is needed to implement an intervention" ${ }^{16}$.

It is worth stressing that NIC is being constantly updated and reviewed, carrying out studies to include or exclude interventions and activities, thus contributing to increasingly standardize the language used by nursing.

It was also observed that non-pharmacological pain relief methods are increasingly present in studies, which shows a new vision of professionals, especially of the nursing team, who promote painful patients' education and encourage them to look for such resources.

Finally, it has been observed that preoperative orientations about pain were present in three articles and have shown to be effective in decreasing anxiety and decreasing reports of postoperative pain.

\section{CONCLUSION}

Most interventions mentioned in the articles are part of the activities of the intervention pain control proposed by NIC. However, there are few clinical trials about this subject, especially with adults, result which may be related to the difficulty in evaluating pain in the clinical practice, as well as to the lack or records about its evaluation. It is suggested, then, that such studies are carried out to link theory to practice, contributing to a moment where evidence-based nursing is present and is increasingly getting stronger.

\section{REFERENCES}

1. Nóbrega MM, Silva KL. Fundamentos do cuidar em enfermagem. $2^{\text {a }}$ ed. Belo Horizonte: ABEN; 2008/2009. 17-21p.

2. Conselho Federal de Enfermagem (COFEN). Resolução COFEN nº 358/2009: Dispóe sobre a Sistematização da Assistência de Enfermagem e a implementação do Processo de Enfermagem em ambientes, públicos ou privados, em que ocorre o cuidado profissional de Enfermagem, e dá outras providências. Brasília; 2009.

3. Conselho Federal de Enfermagem (COFEN). Resolução COFEN nº 272/2002. Rio de Janeiro, 2002.

4. NANDA Internacional. Diagnósticos de enfermagem da NANDA: definiçōes e classificaçóes, 2009-2011. Porto Alegre: Artmed; 2010.

5. Rigotti MA, Ferreira AM. Nursing interventions to the patient with pain. Arq Cienc Saúde. 2005;12(1):50-4.

6. de Souza Teixeira CR, Becker TA, Citro R, Zanetti ML, Landim CA. [Validation of nursing interventions in people with diabetes mellitus]. Rev Esc Enferm USP. 2011;45(1):173-9. Portuguese.

7. da Silva YB, Pimenta CA. [Analysis of nursing registries of pain and analgesia in hospitalized patients]. Rev Esc Enferm USP. 2003;37(2):109-18. Portuguese. 
8. Paula GR, Reis VS, Ribeiro FA, Gagliazzi MT. Assistência de enfermagem e dor em pacientes ortopédicos na recuperação anestésica, no Brasil. Rev Dor. 2011;12(3):265-9.

9. Restrepo-Medrano JC, Rojas JG. Fibromialgia qué deben saber y evaluar los profesionales de Enfermería? Invest Educ Enferm. 2011;29(2):305-14.

10. Abreu MA, Reis PE, Gomes IP, Rocha PR. Manejo não farmacológico da dor em pacientes com câncer: revisão sistemática. Online Braz J Nurs. 2009;8(1): Disponível em: <http://www.objnursing.uff.br/index.php/nursing/article/ view/j.1676-4285.2009.2222/475 >. Acesso em: 06 jul 2013.doi: http://dx.doi. org/10.5935/1676-4285.20092222.

11. Popov DC, Peniche Ade C. [Nurse interventions and the complications in the post-anesthesia recovery room]. Rev Esc Enferm USP. 2009;43(4):953-61. Portuguese.
12. Gomes FS, Moreira LF, Andrade PG, Santos FM. Sistematização da assistência de enfermagem a pessoa portadora da síndrome de Churg-Strauss: estudo de caso. Rev Min Enferm. 2007;11(4):470-4.

13. da Silva DG, Marques IR. [Nursing interventions for patients with sickle cell during pain crisis]. Rev Bras Enferm. 2007;60(3):327-30. Portuguese.

14. Heye ML, Foster L, Bartlett MK, Adkins S. A preoperative intervention for pain reduction, improved mobility, and self-efficacy. Appl Nurs Res. 2002;15(3):174-83.

15. Niño BF. Intervención de enfermería em el manejo del dolor del paciente quemado. Actual Enferm. 2001;4(1):20-6.

16. Bulechek GM. Classificaçáo das intervençôes de enfermagem: (NIC). Rio de Janeiro: Elsevier; 2010. 